\title{
Venture financing in the New Period under Crowd-funding Financing Perspective
}

\author{
Qiang Wang ${ }^{\mathrm{a}}$, Shunhong $\mathrm{Ji}^{\mathrm{b}}$ \\ School of Economic Management, Nanjing University of Science and Technology, \\ Nanjing 210094, China. \\ am15651800599@163.com, bjishunhong889@163.com
}

Keywords: Venture financing, Crowd-funding, financing risk.

\begin{abstract}
Shortage of funds is the biggest problem in entrepreneurial dilemma and financing difficulties is a much major bottleneck in the development of enterprises. As a new online financial vehicle, crowd-funding has developed rapidly around the world in recent years for its low cost and high convenience. It gradually becomes the new impetus of venture financing in Web 2.0. How to deal with the relationship between innovation and risk in the development of crowd-funding reasonably has become a new research point among Chinese and overseas scholars. On account of the analysis of international and domestic status, we demonstrate and study the problems and risk during the development of crowd-funding. On this basis, we discuss the future research direction about the crowd-funding and propose corresponding policies aimed at perfecting.
\end{abstract}

\section{Introduction}

Entrepreneurship has played an important role in promoting economic growth, increasing jobs capacity and technological innovation. However, with high transaction costs of venture capital financing project and asymmetric information, the prosperity of entrepreneurial activity is limited strictly. Given the current domestic banking system and venture capital fund system, we ought to take much more innovation about investment \& crowd-funding in venture capital financing system.

Network technique provides a platform for the exchange of information across different space or time. It offers the potential to reduce transaction costs and promote production. With the online platform, venture financing innovation has also taken considerable development, especially in crowd-funding. On one hand, crowd-funding financing decreases the threshold for entrepreneurs. On the other hand, there are many problems in practice challenging the traditional financing regulatory system. What's more, compared with foreign countries, legal and policy environment in China have a significant difference in operational mechanisms and regulatory policies, resulting a more complex and diversified crowd-funding risk.

The study will focus on crowd-funding analyzing its origin, classification, operating mode, advantages and risks to offer theoretical reference and practice guidance for entrepreneurs carrying out crowd-funding model.

\section{Theory and Literature review}

Traditional venture Financing. Financing channels refer to the direction enterprises financing, which reflecting the sources and flow of funds. It is crucial to understand the type of financing for further survival and development. Therefore, the ability to raise capital efficiently is key factor to business success. The traditional venture capital financing consists of six major ways, shown in the following figure 1. 


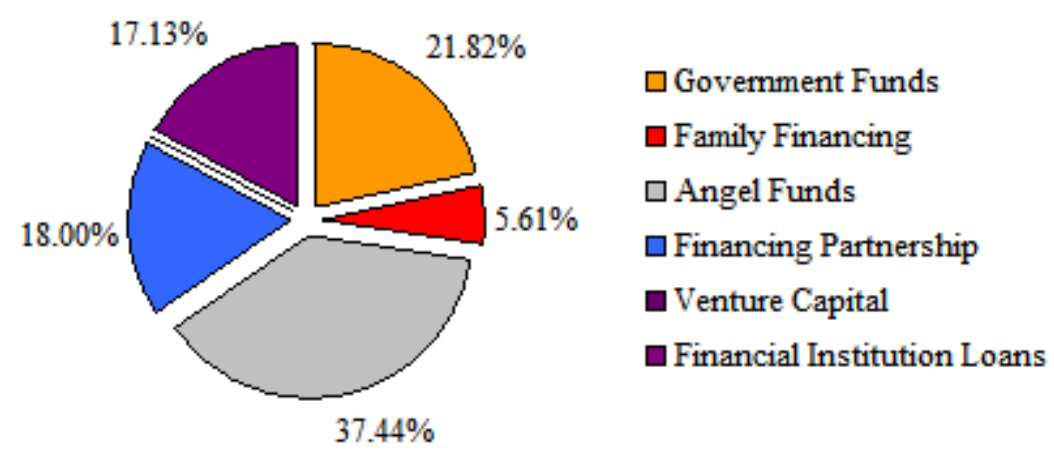

Fig. 1 Traditional venture capital financing construction

Concept. Crowd-funding comes from crowd-sourcing and micro-financing. It means raising funds from the public. The applicant introduces their crowd-funding project through crowd-funding platform to gain investment and support from people who browsing them.

The prototype of crowd-funding could date back to 1885. Joseph Pulitzer, a publisher, published this project in New York World hoping to get funding and claim corresponding reward to donors. Eventually, the project received support from more than 12 million people and raised $\$ 100,000$ successfully. In 2011, the term crowd-funding was officially included in the Oxford Dictionary, defined as to raise small amounts of money from people or enterprises via the Internet to approach a project.

Classification. Crowd-funding financing can be divided into four types, reward-based crowd-funding, equity-based crowd-funding, lending-based crowd-funding and donation-based crowd-funding, depending on the return. Reward-based crowd-funding refers to project whose sponsors may obtain non-financial rewards in return for their funds. It is generally applied to product financing of innovative projects, especially for movies, music and technology products. Equity-based crowd-funding offers securities for sponsors to raise funds for projects. Typically, equity crowd-funding commonly used in start-ups or the beginning of SMEs, particularly in the software, computer and media companies. Different from bank loans, lending-based crowd-funding borrows from sponsors through public platform. In donation-based crowd-funding, both parties involved formed a contract without any substantial reward. Over the past decade, many non-governmental organizations have adopted this model to attract donations for specific projects.

The crowd-funding mostly used in practice are reward-based crowd-funding and equity-based crowd-funding. The comparisons between them are shown in table 1.

Table 1 Reward-based and equity-based crowd-funding

\begin{tabular}{ccc}
\hline Type & Reward crowd-funding & Equity crowd-funding \\
\hline Return & Entity & Transfer part (10\%-30\%) stake \\
\hline $\begin{array}{c}\text { Financing } \\
\text { Amount }\end{array}$ & Below 1 million RMB & 1 -10 million RMB \\
\hline $\begin{array}{c}\text { Requirements } \\
\text { No need to set up a } \\
\text { company }\end{array}$ & $\begin{array}{c}\text { Must have an prior established } \\
\text { company }\end{array}$ \\
\hline $\begin{array}{c}\text { Investors } \\
\text { qualifications }\end{array}$ & All registered users & Qualified investors \\
\hline $\begin{array}{c}\text { Investor } \\
\text { Rights }\end{array}$ & $\begin{array}{c}\text { Only have the right to } \\
\text { recommend }\end{array}$ & $\begin{array}{c}\text { Shareholders and certain stake } \\
\text { can join the board of directors }\end{array}$ \\
\hline Return period & Several months to one year & After a profit start-ups gained \\
\hline
\end{tabular}

\section{Risk and Response}

Crowd-funding Financing Processes. A crowd-funding financing process in a venture project involves three types of participants: originator (entrepreneurs), supporters (investors) and platform. The initiator introduces the project and demonstrates the target amount of financing, dates and the expected returns through crowd-funding platform. Accordingly, investors choose the investment objectives based on their judge, such as expected return. All online users can become marketing 
targets on the Internet for large browsing traffic. Not only does the platform promote transactions between originator and sponsors, but also provide services such as project auditing. The specific crowd-funding financing process is shown in the following figure.

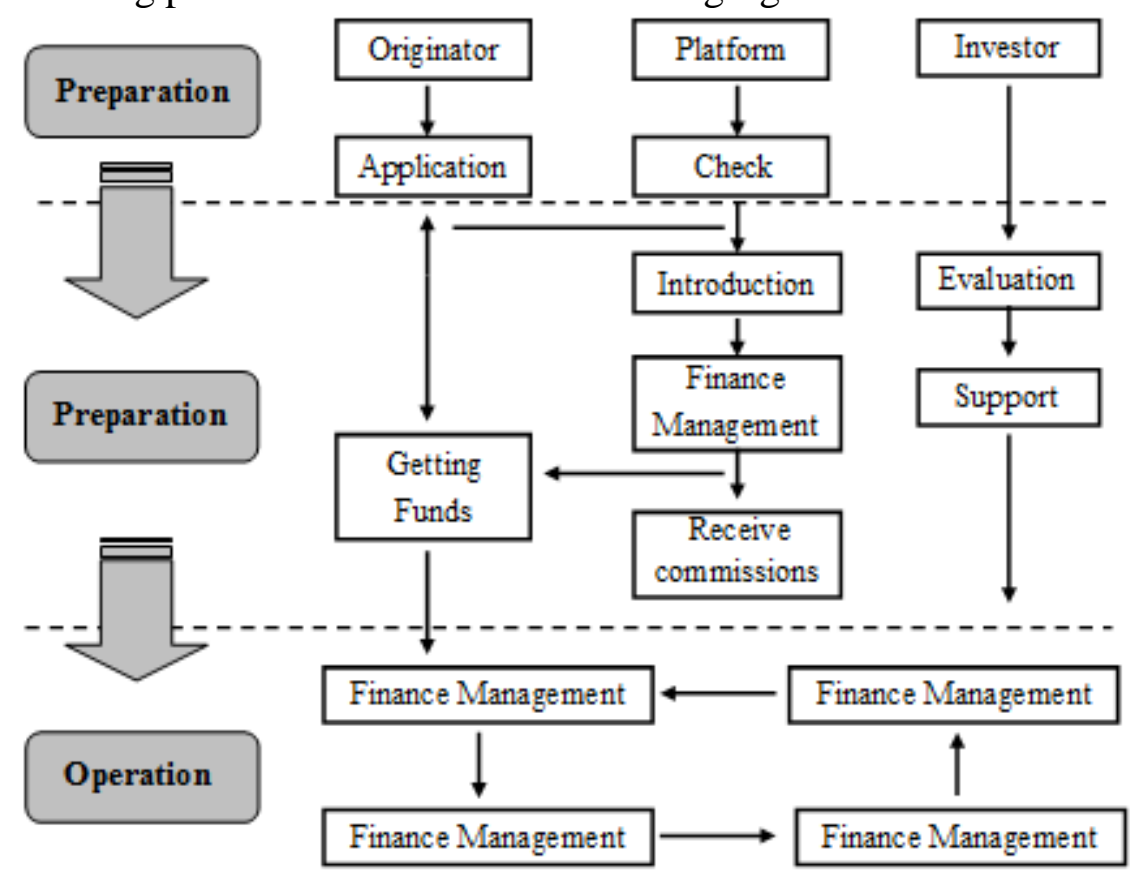

Fig. 2 The flow chart of crowd-funding financing process

Crowd-funding Financing Risks. Schwienbach \& Benjamin (2013) found that entrepreneurs do not have to disclose their ideas and business plans in the traditional mode of project financing, but in crowd-funding platform they must introduce the content about projects, which would result in plagiarisms. Wells Nicholas (2013) pointed out that equity crowd-funding raised the issue of intellectual property protection in the United States. The core risk initiator faced was that SEMs were less likely to afford the cost of maintaining business and legal rights when their own interests were violated. Colgren David (2014) concluded that crowd-funding is a combination of big data, cloud technology and social platforms, risk of fraud arising from this innovative model challenging the regulatory authorities. Eleanor Kirby \& Shane Worner (2014) also said that information released by enterprises is difficult to distinguish in Web 2.0 and investors often lack the expertise to make precise decisions.

According to the flow of crowd-funding financing, we summarize the risk in the study as follows.

Firstly, crowd-funding platform may be faced with the risk of legal status for its unclear legal status. The commission and transaction service will bring constitute brokers.

Secondly, due to imperfect intellectual property protection system and the difficulty to protect, initiators' innovation or ideas are likely to be plagiarized. Moreover, securities regulatory commission has clearly published the nature of equity crowd-funding and declared that it didn't have the qualification for a public stock offering.

In addition, there are much more risks investors need to response. The first one is moral hazard. Leading investor with following investor mechanism, aimed at spurring non-professional investors to participate in crowd-funding, would lead to the partnership between lead investors and initiators under asymmetric information and harm the interest of following investors. The second is over-financing. Once exceeding the target financing amount, the risk of investing will increase. Over-financing may weaken the initiator's ability to control and use the target funds.

Although these risks above are not directly targeted at entrepreneurs, they will be involved in the financing process. Therefore, it calls entrepreneurs taking more consideration to know and making active measures to deal with them.

Crowd-funding Financing Risk Response. Establish a regulatory framework of consumer protection. Crowd-funding is included in the scope of financial regulation in this framework. 
Regulation on crowd-funding financing platform should be based on consumers. It involves transparency of operation and financing, management and control of funds and information and payment security. Under this circumstance, information is checked by banking supervisory authorities and non-banking financial services regulators. A single set of financial regulatory makes the supervision more targeted and proactive.

Publish crowd-funding financing regulation. The regulation revision should be based on the current securities law and extensive solicitation of domestic researchers' suggestion. A major goal of the regulation is to protect the interests of small investors and promote entrepreneurship development. With the assistance, the industry will get standard crowd-funding platform, convenient venture capital financing and clear investor classification. Meanwhile, more detailed provisions should be enacted to explain crowd-funding platform access conditions, routine operation, internal control and marketing. Furthermore, crowd-funding platform should transfer from online into online-offline. Online-offline platform will constantly enhance the confidence of investors and entrepreneurs.

Strengthen the equity crowd-funding financing and its secondary market. To increase market liquidity, crowd-funding financing could establish secondary market for equity crowd-funding financing. The introduction of angel investment will address the problem as well. After the success of the financing, the platform sets up a trust scheme for each project. Equity and funds will be managed by the Trust on behalf of holders. In addition, the lead investor who launched VC / PE investment required to assume project management duties with regular or irregular supervision of the entrepreneur's use of funds and the progress of the project.

\section{Conclusion}

This study introduces the concept of crowd-funding financing and makes literature review about related concepts. On this basis, we put more analysis on the role of crowd-funding financing. Equity crowd-funding has resolved the financing problem of SMEs effectively. It provides a platform for start-ups to connecting originator and investor and guiding private capital involved in entrepreneur. Meanwhile, it decreases the threshold for financing and changes the pattern of investing channels. However, the risk of equity crowd-funding should not be under-estimated. Improper operation will bring huge losses to participants and harmful effect to the stability of the financial order. Therefore, we propose measures for the corresponding risks to promote crowd-funding developing stably. In the future, it will become an important part of Chinese multi-level capital market and play an important role in promoting the capital market on the entity economy.

\section{References}

[1] Armbrister, Molly, Crowd-funding raises hopes and concerns, J. Northern Colorado Business Report. 22 (2012) 7-11.

[2] Colgren, David, The Rise of Crowd-funding: Social Media, Big Data, Cloud Technologies, J. Strategic Finance. 04 (2014) 56-59.

[3] Wells Nicholas, The risks of Crowd-funding, J. Risk Management. 02 (2013) 26-32.

[4] Hazen, Thomas, Crowd-funding or Fraud-funding? Social Networks and the Securities Laws - Why the Specially Tailored Exemption Must be Conditioned on Meaningful Disclosure, J. North Carolina Law Review. 03 (2012) 32-35.

[5] Myriam Amara, Crowd-funding: Determinants and Motivations of the Contributors to the Crowd-funding Platforms, J. Environment for Innovation Journal. 16 (2015) 67-71.

[6] Schwienbach Armin, Benjamin Larralde, Crowd-funding of small entrepreneurial ventures, J. Handbook of entrepreneurial finance. 08 (2013) 29-32. 
[7] Shufen Hu, Collegiate Business Financing Mechanism Innovation-based venture capital financing needs, J. Management and Administration. 12 (2014) 149-152.

[8] Kaijun $\mathrm{Wu}$, Plight of college students venture financing and Countermeasures, J. Technology \& Management Research. 08 (2012) 25-28.

[9] Zhihua Qin, Bin Xu, Minghui Zhang, Theoretical model of social capital in venture capital financing mechanism explained, J. Management Review. 5 (2012) 10-20.

[10] Wang Ana, Crowd-funding financing business model and risk analysis, J. Theory of Finance and Economics. 3 (2014) 99-103.

[11] Xiao Hua, Development of the US House Financial Model and its Implications to China, J. South China Finance. 1 (2013) 52-56. 